\title{
The Middle School Students' Attitudes towards Turkish Course and Perceptions for Turkish Teachers
}

\author{
Mustafa Turkyilmaz * \\ Ahi Evran University, TURKEY
}

\author{
Mustafa Armut \\ Ahi Evran University, TURKEY
}

Received: September 5, 2018 - Revised: September 26, 2018 • Accepted: September 28, 2018

\begin{abstract}
The purpose of this study is to determine the attitude towards Turkish Course and reveal the perception of students towards Turkish Course and teacher. In this context, a personal information form and Attitude Towards Turkish Course (ATTC) Scale were applied to 419 students who receive education in the center of Kirsehir province, in Turkey. In addition to that, the metaphors of students towards Turkish teacher and course were compiled by means of semi-structured interview form. The students were also required to draw pictures that express their feelings towards Turkish Course. The results can be summarized as follows: it was seen that Turkish teachers were likened to an "angel", "cotton" and "panda", and happy emojis and heart figures were drawn towards Turkish Course. It was understood that the attitudes of- female students in comparison to male students, the ones who possess a phone to the ones who do not, the ones who have a higher literacy level to the ones with lower literacy level, the ones with more social media followers to the ones with less followers and the ones who spend more extracurricular time with to the ones who do not- have been developed more positively.
\end{abstract}

Keywords: The attitudes for Turkish course, the perceptions of Turkish teachers, middle school students.

To cite this article: Turkyilmaz, M., \& Armut, M. (2018). The middle school students' attitudes towards Turkish course and perceptions for Turkish teachers. European Journal of Educational Research, 7(4), 913-923. doi: 10.12973/eu-jer.7.4.913

\section{Introduction}

Expressing the feelings and emotions is not an easy action to perform for human beings. Therefore the poet Orhan Veli also said "I can not express". Such as the difficulties occur in terms of the action of expressing, it is not so easy to understand the message that is sent through a verbal or written source. The individual who wish to express himself/ herself more effectively and to understand what is told embarks on a quest of using different methods and technologies for effective understanding and expression. The person who is not able to express himself/herself with mimics and gestures have been forced to make gnarled voices (Taser, 2012; Aksan, 2003). The concern of expression is the underlying reason of making gnarled voices. Additionally, in the modern times that visuality is dominating, human beings try to express themselves intensely through visual communication tools. Just as the individuals who endeavor to find solution to understand and express, societies also choose the way of employing modern devices prevalently and frequently in order to understand and express.

In this context, the libraries consist of ten thousands of books and information expressed by terabytes are the products of understanding and expressing. Language courses have a fundamental importance in terms of individual's access to knowledge and expressing new knowledge. While the communication established in real life is a product of parents at a basic level, schools are the institutions which makes this communication effective. Turkish courses and teachers are responsible of an important task in this context. Therefore, it is important to determine the perception level towards Turkish course and Turkish teacher, factors that can affect the attitude and perception.

Allport is one of those who emphasized the importance the concept of attitude that has started to be examined in $19^{\text {th }}$ century, and its measurement. According to him, attitude is a mental and neural state of readiness, organized through experience, exerting a directive or dynamic influence upon the individual's response to all objects and situations with which it is related (Allport, 1967: 3).

"Attitudes reflect information that was obtained after the experiences between an object or a phenomenon. Attitudes are evaluative judgements that are a summarized combination of cognitive and affective behaviors. This evaluation

\footnotetext{
* Corresponding author:

Mustafa Turkyilmaz , Ahi Evran University, Turkish Education, Kirsehir / Turkey.

Email: turkyilmazmustafa@yahoo.com
} 
possesses a different level of strength in terms of the transformation of continuity, resistance and attitude to behavior (Crano \& Prislin, 2006: 347).

On the other hand, according to Fishbein and Ajzen (1975: 6), attitude is defined as a positive or negative response that has a learned continuity towards an object. Attitudes consist of three components (Oskamp \& Schultz, 2005:9; Tavsancil, 2006: 72; McKenna, Kear \& Ellsworth, 1995: 937; Bohner \& Wanke, 2002: 5; Brown, 2006:49; Incelioglu, 2004: 26-31). These are affective, behavioral and cognitive components.

In this study, it was aimed to present the perceptions of students towards their teachers through metaphors in addition to determining their attitudes towards Turkish course. From this aspect, it is also required to emphasize the concept of metaphor. Metaphors are strong tools of expression that regulate thoughts on ourselves and other people, incidents and nations (Berliner, 1990). In parallel with this definition, Oxford et. al (1998) express that the metaphors are the ways of expression of situations and phenomena in every field, including language learning and teaching. Metaphors also regulate the thought of the world and perceiving the reality (de Guerrero \& Villamil, 2002). Metaphors are conceiving something according to something else and in this way reveal people's way of thinking and also determine their form of action (Lakoff \& Johnson, 2005). In parallel to this, Manguel (2018: 9) states that "Language refer to metaphors as a confession of its deficiency of communication in order to create a wider space". He explained the function and starting point of metaphors by expressing that "The experiences in a field are lightened with the ones that were gained somewhere else through metaphors. Berliner (1990) stated that the teacher roles are tried to be conceptualized through metaphors. For example, he wrote that if the high school teachers were seen as "informative" it means that an image that a teacher explains the subject by disregarding that whether it is understood or not. In a similar way, if a teacher considers himself/herself as "informative" it means that there can be an understanding that implies information can be given only by teachers. When the definitions of attitudes and metaphors provided above are considered, it was aimed in this study to determine attitudes towards Turkish course and metaphors towards Turkish teachers by thinking that both of the concepts would provide information regarding action, perception and perspective.

There are some studies which investigated the relations between the attitude towards Turkish course and some techniques and methods applied in the scope of Turkish course in the literature (Akin,\& Cecen, 2005; Corek, 2006; Belet,\& Yasar, 2007; Kayiran, Iflazoglu, 2007; Kapar-Kuvanc, 2008; Sahinli, 2008; Aslan, 2009; Akkaya, 2011; Arslan, Sahin, Sahin,\& Akcay, 2011; Tuzemen, Kardas, 2017; Yildirim,\& Erdogan, 2016). A few studies also investigated the attitudes towards Turkish course through a survey design (Ates, 2008; Kaya, Arslantas,\& Simsek, 2009; Bolukbas, 2010; Fidan,\& Eren, 2017; Baki, 2018). In these researches, relations between the attitude towards Turkish course and attitude towards reading and gender of the students, education level of students' parents, socio-economic level of the students' families, academic achievement of students. Only a paper was found in the literature related to perceptions about Turkish course teachers (Gedikli, 2014). In this study, metaphors were used for determining the perceptions about Turkish course teachers. As seen in the literature, there are studies about attitudes towards Turkish course and perceptions about Turkish course teachers. However there is no study investigating the current conditions both about Turkish course and Turkish course teachers using metaphors produced by students. Additionally it can be stated that both perception and attitude against things can change rapidly. So, perceptions and attitudes against Turkish course and Turkish course teacher also can change. For this reason, new studies must be conducted in this field. It is known that constructivism approach has been followed since 2005 in Turkish education system according to the Turkish course curriculums. So, it is also possible through this study to reveal whether the Turkish course teachers follow a Turkish course in convenience with the constructivism approach or they still teach Turkish lessons according to traditional methods.

\section{Research Problems}

1. What is the level of secondary school students towards Turkish course?

2. Do the level of attitudes of secondary students towards Turkish course differ according to grade level, gender, level of reading, profile numbers on social media, condition of possessing a cell phone, being pleased about Turkish course teacher, situation of doing extracurricular activities with their Turkish teacher, education level of parents

3. What are the analogies drawn by participants regarding Turkish teacher?

4. Do the metaphors that participants developed according to their gender and grade level differentiate?

5. What are the creature/thing that participants would like to see their Turkish teachers as?

6. How participants depicture their feelings towards Turkish course?

\section{Methodology}

\section{Research Model}

In this study that aims to determine the perceptions of secondary schools students towards Turkish course and metaphors towards Turkish teachers, the qualitative and quantitative research methods were employed. For the purpose of determining students' attitudes towards Turkish course and reveal the relationship between certain 
variables, the correlational survey model was used. The correlational survey models are models that aim to examine the existence and/or degree of a change between two or more variable (Karasar, 2008: 81). In addition, in this study, the phenomenology which is among the qualitative research methods, in order to reveal the perceptions of secondary school students towards Turkish teachers was employed. (Yildirim \& Simsek, 2013). Additionally, the phenomenology method which is a qualitative method was employed in order to reveal the perceptions of the secondary students towards Turkish course teachers.

\section{The Data Collection Tool, Data Collection Process and Data Analysis}

In this study, Attitude Towards Turkish Course Scale that was developed by Topcuoglu Unal and Kose (2014) was employed. The scale that was developed by researchers consists of three dimensions and 27 items. The scale was tested through exploratory and confirmatory factor analysis by the researchers of this paper. In this regard, Tavsancil (2006: 206), states that the factor analysis of a scale that was used previously should be done by a confirmatory factor analysis. In this direction, researchers of this paper tested the Attitude Towards Turkish Course Scale through a second level confirmatory factor analysis with a non-sample group. In terms of the confirmatory factor analysis, the model suitability criteria values of RMSEA (Root Mean Square Error of Approximation), SRMR (Standardized Root Mean Square Residual), GFI (Goodness of Fit Index), AGFI (Adjusted Goodness of Fit Index), CFI (Comparative Fit Index), NFI (Normed Fit Index) were taken into the consideration for the suitability of the structure. It was determined that the $\mathrm{x}^{2}$ value that differs according to the sample size is 900.48 and degree of freedom ( $\mathrm{df}$ ) is 321 . On the other hand, $\mathrm{x}^{2} / \mathrm{df}$ is 2.80. For this value, it can be said that it expresses a reasonable fit (Cited by Kline, 2005: 137, from Bollen, 1989). According to the results obtained, the RMSEA value which presents a good fit if it is below 0.05 (Browne \& Cudeck, 1993: 144) was found as 0.075, and the SRMR value which is accepted as positive if it is below 0.10 (Kline, 2005: 141) was found as 0.066 . The RMSEA and SRMR value of 0 or any value that is approximate to zero demonstrate the perfection of the model (Brown, 2006: 84, Byrne, 2010: 80). Furthermore, it as determined that the GFI value that needs to be above 0.90 for a suitable model (Kline, 2005: 145) was determined as 0.83; and AGFI value was determined as 0.80 . GFI and AGFI values can take a value between 0 and 1 in the case of the suitability of the model; they should be approximate to 1 yet cannot be negative (Joreskog \& Sorbom, 1993: 123; Raykov \& Marcoulides, 2006: 43). It was determined that the NFI value which should be approximate to 1 between the values of $0-1$ such as AGFI and GFI according to Raykov and Marcoulides (2006: 44) is 0,91; and the CFI value that needs to be approximate to 1 between the values of 0-1(Raykov \& Marcoulides, 2006: 44; Brown, 2006: 85; Byrne, 2010: 78) is 0,94. According to the obtained indicators, it can be said that the model is acceptable. In addition to this process the reliability test was conducted. The results revealed that Cronbach's Alpha was .809. This value indicated that the scale was reliable (Field, 2005: 668). In this way, the relevant scale was employed in the research in order to determine the attitude of students toward Turkish course. Apart from this, the personal information that is thought to be examined in association with the responses given to the scale to see the relationship was collected through Personal Information Form.

In order to determine the perceptions of students towards Turkish course and teacher, a qualitative interview form was prepared; and in this form the students were asked to draw their feelings towards Turkish course, draw analogies on their Turkish teacher on something that they find appropriate and to explain the reasons of this analogy. In this semi-structured form, the students were asked to write what they would like their teacher to be like except that their current thought. For the reliability and validity of the qualitative data, firstly prepared semi-structered form was presented to opinions of two experts about Turkish language. These experts evaluated the form in terms of convenience for the rules of Turkish language, for the language level of the middle school students and for spelling and punctuation. While determining which statements used by the students were be evaluated as metaphors, two researchers compared their findings. The statements which both of the two researchers thought as metaphors were recorded as metaphors. While decoding the drawings of the students, an expert in the field of psychological counseling and guidance was consulted.

Attitude Towards Turkish Course Scale and the prepared forms were applied to students in one lecture hour. In data analysis, the situation of whether the data set displays a normal distribution or not was determined in order to decide which techniques to be used. According to Kolmogrov- Simirnov results, normal distribution was determined for the general average was determined as $(D(419)=0.63$; $\mathrm{p}>.005)$, for activities towards lecture dimension as $(D(419)=0.68$; $\mathrm{p}>.005)$, for affection towards lecture dimension as $(D(419)=0.65 ; \mathrm{p}>.005)$ and for negative attitude towards lecture as $(D(419)=0.55 ; \mathrm{p}>.005)$. With these results, t-test and one way ANOVA analysis was employed (Field, 2005).

\section{Population and Sample}

There are 13.169 middle school students having education in state schools in Kirsehir according to National Educational Management of Kirsehir. It was not possible to reach whole universe. So, sampling way was chosen. The random sampling method was conducted. The universe whose data was collected on 2017-2018 winter semester was consisted of 419 randomly selected secondary school students who receive education in the center of Kirsehir province. 101 of the students are fifth grade, 117 of the students are sixth grade, 101 of the students are seventh grade and 100 of the students are eighth grade students. In addition, 219 of these students are females and 200 of them males. 


\section{Findings}

In this section the research problems are answered.

Table 1. General Values Regarding Students Attitudes' towards Turkish Course and Averages

\begin{tabular}{lcc}
\hline ATTC & $\overline{\boldsymbol{X}}$ & SD \\
\hline General & 2,85 &, 530 \\
Activities towards Lecture & 3,20 &, 994 \\
Affection and interest towards lecture & 2,73 &, 474 \\
Negative Attitude towards lecture & 2,88 &, 651 \\
\hline
\end{tabular}

Table 1 reveals that secondary school students have a medium/indecisive (2.85) (Tasdemir, 2003) level of attitude towards the Turkish course. In addition, it is understood that they have a medium level of attitude in terms of the subdimensions that compromise the Attitudes Towards Turkish Course.

Table 2. One Way ANOVA Analysis Towards the Relationship Between Students' Attitudes Towards Turkish Course and Grade Levels

\begin{tabular}{cccccccc}
\hline & Grade Levels & $\mathbf{N}$ & $\overline{\boldsymbol{X}}$ & $\mathbf{d f}$ & $\mathbf{F}$ & $\mathbf{p}$ & $\begin{array}{l}\text { Significant } \\
\text { Difference }\end{array}$ \\
\hline \multirow{3}{*}{ ATTC } & 5 & 101 & 3,15 & & & & \\
& 6 & 117 & 2,97 & 3 & 34,077 &, 000 & EXISTED \\
\hline
\end{tabular}

According to the results of the analysis, the average scores towards different grade level students' attitudes towards the Turkish course differentiate at significance level. It is seen that all attitude grades are decreasing from fifth grade to eighth grade. The scores of fifth-grade students were actualized higher than all upper-grade level students' attitude scores at a significance level. The attitude score of sixth-grade students is higher than seventh and eighth level students at a significant level. The score of seventh-grade students is higher than eighth-grade students at a significant level.

Table 3. T-Test Results Between Students' Genders and Attitude Scores

\begin{tabular}{llccccc}
\hline ATTC & Gender & $\mathbf{n}$ & $\bar{X}$ & SS & t & p \\
\hline General & Female & 219 & 2,91 &, 478 & \multirow{2}{*}{2,796} & \multirow{2}{*}{005} \\
Average & Male & 200 & 2,77 &, 573 & \\
\hline
\end{tabular}

According to Table 3 attitudes of the female students are higher in a more significant and significant manner in comparison to male students.

Table 4. One Way ANOVA Analysis Towards the Relationship Between Students' Attitudes Towards Turkish Course and Reading Levels

\begin{tabular}{cccccccc}
\hline & Levels & $\mathbf{N}$ & $\overline{\boldsymbol{X}}$ & $\mathbf{d f}$ & $\mathbf{F}$ & $\mathbf{p}$ & $\begin{array}{l}\text { Significant } \\
\text { Difference }\end{array}$ \\
\hline \multirow{3}{*}{ ATTC } & Good & 243 & 2,94 & & & & \\
& Medium & 161 & 2,72 & 2 & 11,921 &, 000 & EXISTED \\
& Poor & 11 & 2,49 & & & & \\
\hline
\end{tabular}

According to Table 4, the attitudes of students towards Turkish course who consider themselves as good readers were actualized at a higher level in comparison to the ones who consider themselves as weak level readers. 
Table 5. One Way ANOVA Analysis towards the Relationship between Students' Attitudes towards Turkish Course and Number of Profiles they Have on Social Media

\begin{tabular}{cccccccc}
\hline & $\begin{array}{c}\text { Number of } \\
\text { Profiles }\end{array}$ & $\mathbf{N}$ & $\overline{\boldsymbol{X}}$ & $\mathbf{d f}$ & $\mathbf{F}$ & $\mathbf{p}$ & $\begin{array}{c}\text { Significant } \\
\text { Difference }\end{array}$ \\
\hline & None & 76 & 2,94 & & & & \\
ATTC & 1 & 236 & 2,88 & & & & \\
& 2 & 71 & 2,72 & 4 & 3,890 &, 004 & EXISTED \\
& 3 & 25 & 2,69 & & & & \\
\hline
\end{tabular}

When Table 5 is addressed in general terms, it is seen that the attitudes of secondary students decrease when the number of profiles they have on the social media increase. On the other hand, the different attitude scores among the groups occurred between the ones who do not have any profiles and the ones who stated that they have 4 profiles, in favor of the ones who do not have any profiles.

Table 6. T-Test Results Between Students'Situation of Possessing the Cellphone and Attitudes Towards Turkish Course

\begin{tabular}{llccccc}
\hline ATTC & Cellphone & $\mathbf{n}$ & $\bar{X}$ & SD & t & p \\
\hline \multirow{2}{*}{ General mean } & Existed & 236 & 2,76 &, 540 & \multirow{2}{*}{3,867} & \multirow{2}{*}{000} \\
& None & 182 & 2,96 &, 497 & \\
\hline
\end{tabular}

In Table 6, a finding which is similar to the number of profiles on social media was presented. Just as the fact that increase in the number of profiles has a negative impact on attitudes towards Turkish course, the scores of the ones who do possess a phone were also lower in comparison to the ones who do not possess a phone. Furthermore, this difference between the scores is in favor of the ones who do not possess a phone.

Table 7. One Way ANOVA Analysis Towards the Relationship Between Students' Attitudes Towards Turkish Course and Their Affection Towards Teacher

\begin{tabular}{cccccccc}
\hline & Levels & N & $\overline{\boldsymbol{X}}$ & df & F & p & $\begin{array}{c}\text { Significant } \\
\text { Difference }\end{array}$ \\
\hline \multirow{3}{*}{ ATTC } & More & 344 & 2,93 & & & & \\
& Little & 64 & 2,49 & 2 & 29,799 &, 000 & EXISTED \\
& Any & 9 & 2,20 & & & & \\
\hline
\end{tabular}

According to Table 7, it is understood that the affection towards teacher also affects the positive attitude towards the Turkish course. The attitudes of students who stated that they like their Turkish teachers very much also occurred at a significant and positive level.

Table 8. T-Test Results Between Students' Status of Participating Extracurricular Activities and Situation of Attitude Scores

\begin{tabular}{llccccc}
\hline ATTC & Activity & $\mathbf{n}$ & $\bar{X}$ & SD & t & p \\
\hline General & I do participate & 257 & 2,96 &, 469 & \multirow{2}{*}{6,189} & \multirow{2}{*}{000} \\
Average & I do not participate & 148 & 2,63 &, 576 & \\
\hline
\end{tabular}

According to Table 8, it can be said that extracurricular activities carried out with Turkish teacher improves students' attitudes' towards Turkish lecture. In addition, attitude scores of the students who make activities with the Turkish teacher occurred positively and significantly in comparison to the ones do not make such activities.

Table 9. One Way ANOVA Analysis Towards the Relationship Between Students' Attitudes Towards Turkish Course and Maternal Education Levels

\begin{tabular}{cccccccc}
\hline & $\begin{array}{c}\text { Level of } \\
\text { Education }\end{array}$ & $\mathbf{N}$ & $\overline{\boldsymbol{X}}$ & $\mathbf{d f}$ & $\mathbf{F}$ & $\mathbf{p}$ & $\begin{array}{c}\text { Significant } \\
\text { Difference }\end{array}$ \\
\hline & Primary School & 67 & 2,95 & & & & \\
Secondary & 88 & 2,91 & & & & \\
ATTC & School & & & 3 & 1,910 &, 127 & NONE \\
& High School & 144 & 2,82 & & & \\
\hline
\end{tabular}


According to Table 9, the increase in the level of maternal graduation level also affects the attitude towards Turkish lecture negatively. However, the attitude score between the groups is not at a significance level.

Table 10. One Way ANOVA Analysis Towards the Relationship Between Students' Attitudes Towards Turkish Course and Paternal Education Levels

\begin{tabular}{cccccccc}
\hline & $\begin{array}{c}\text { Level of } \\
\text { Education }\end{array}$ & $\mathbf{N}$ & $\overline{\boldsymbol{X}}$ & $\mathbf{d f}$ & $\mathbf{F}$ & $\mathbf{p}$ & $\begin{array}{c}\text { Significant } \\
\text { Difference }\end{array}$ \\
\hline \multirow{4}{*}{ ATTC } & Primary School & 53 & 3,03 & & & & \\
& Secondary School & 56 & 2,96 & 3 & 4,850 &, 003 & EXISTED \\
& High School & 136 & 2,85 & & & & \\
\hline & University & 165 & 2,75 & & & & \\
\hline
\end{tabular}

According to Table 10, as the level of paternal graduation level increases the attitude towards the Turkish Course affects negatively. However, the attitude score difference between the groups occurred only between primary school and university graduates in favor of the primary school graduates.

In addition to these quantitative findings, the qualitative findings were also included and given explanations were presented in the tables given below.

Table 11. The Metaphors that Students Developed Regarding the Turkish Teachers

\begin{tabular}{|c|c|c|c|}
\hline Group & What Kind of Analogies Were Made? & $\mathbf{N}$ & $\%$ \\
\hline Being Good & Angel/good person/understanding/cotton/panda & 121 & 28,8 \\
\hline $\begin{array}{l}\text { Being informative } \\
\text { and leading }\end{array}$ & $\begin{array}{l}\text { Book/sun/candle/lightness/star/professor/wise/tree/garden/library/torch/ } \\
\text { spelling dictionary / encyclopedia /cupboard }\end{array}$ & 113 & 26,9 \\
\hline Negative & Hitler/boring/dictator/mad/angry/irritable/gunpowder/dragon/mine/annoyed & 40 & 9,5 \\
\hline Blank & - & 32 & 7,6 \\
\hline No Analogy & Teacher/oneself/Turkish teacher/other teachers & 31 & 7,3 \\
\hline $\begin{array}{l}\text { One of the family } \\
\text { members }\end{array}$ & Mother/father/uncle/older brother/older sister & 29 & 6,9 \\
\hline Amusing & Comedian/amusing/theater player/ singer/comedy series /amusement park & 22 & 5,2 \\
\hline Friend & friend/best friend & 13 & 3,09 \\
\hline Discipline & General/pasha & 10 & 2,3 \\
\hline $\begin{array}{l}\text { Positive Analogy } \\
\text { on Plants }\end{array}$ & Rose/flower/grass & 8 & 2,1 \\
\hline Total & & 419 & 100 \\
\hline
\end{tabular}

When the table is examined, it is seen that students focus mainly on their teachers' personality traits and possession of information while they are doing analogies regarding teachers. More than half of the participants put an attention on teachers' traits to be good and leading. Besides that, approximately \%15 of students live it blank or make no analogy.

Table 12. Most Frequent Analogies Made by Participants According to Gender

\begin{tabular}{|c|c|c|c|c|c|}
\hline $\begin{array}{l}\text { Females } \\
\text { Metaphor }\end{array}$ & $\mathbf{N}$ & $\%$ & $\begin{array}{l}\text { Males } \\
\text { Metaphor }\end{array}$ & $\mathbf{N}$ & $\%$ \\
\hline Being informative and leading & 66 & 33,3 & Being Good & 66 & 34 \\
\hline Being Good & 55 & 27,8 & Being informative and leading & 47 & 24 \\
\hline Negative & 17 & 8,58 & Negative & 23 & 12 \\
\hline No Analogy & 16 & 8,08 & No Analogy & 15 & 7,8 \\
\hline One of the family members & 17 & 8,58 & One of the family members & 12 & 6,2 \\
\hline Amusing & 12 & 6,06 & Amusing & 10 & 5,2 \\
\hline Friend & 5 & 2,52 & Friend & 8 & 4,1 \\
\hline Discipline & 4 & 2,02 & Discipline & 6 & 3,1 \\
\hline Positive Analogy to Plants & 6 & 3,03 & Positive Analogy to Plants & 5 & 2,6 \\
\hline Total & 197 & 100 & Total & 192 & 100 \\
\hline
\end{tabular}

According to the Table, it is seen that the most important traits for female students are being informative and leading and being good. On the other hand, while male students put an attention to the same traits, it is understood that the trait of being good is regarded as more important by males in comparison to female students. 
Table. 13. The Analogies that Participants Made According to Grade Levels

\begin{tabular}{llll}
\hline Grade & Analogies & $\mathbf{N}$ & $\mathbf{\%}$ \\
\hline 5 & Being informative and leading & 39 & 41,4 \\
6 & Being Good & 57 & 50,8 \\
7 & Being Good & 30 & 32,6 \\
8 & Being informative and leading & 32 & 35,9 \\
\hline
\end{tabular}

When the analogies that were drawn on grade levels were taken into the consideration, it was seen that at 5th and 8thgrade levels the characteristics of Turkish teachers as being informative and leading was highlighted, and on 6th and 7 th grades the characteristic of a teacher to be a good person is considered as more important.

Table. 14. What are the creatures/things that participants would like to see their Turkish teachers as?

\begin{tabular}{llll}
\hline Group & Analogy & $\mathbf{N}$ & $\mathbf{\%}$ \\
\hline Blank & & 113 & 26,9 \\
No Change & Oneself/same/ as himself, herself/ not like anyone else & 110 & 26,1 \\
The group that starts with «more» & Better, fun, calm, cheerful, funny, witty, friend & 110 & 26,1 \\
and expresses negativity & & 28 & 6,6 \\
Guidance/ formation & Discoverer/painter/eraser/star/magician & 23 & 5,4 \\
As a family member & My mother/father/uncle/sister & 18 & 4,2 \\
Other teachers & Social sciences teacher/former teacher/ Ayla teacher & 17 & 4,2 \\
Invalid analogy & & 419 & 100 \\
Total & & & 100 \\
\hline
\end{tabular}

When the data on what are the creatures/things that participants would like to see their Turkish teachers as, it is seen that the participants mainly left the questions blank or do not want to have a change. Apart from that, it is seen that it is desired mainly by participants that the teacher to have a better or more positive property.

Table. 15. The Outstanding Figures in Students' Drawings on Turkish Course

\begin{tabular}{lcc}
\hline Group & $\mathbf{N}$ & $\mathbf{\%}$ \\
\hline Positive drawings and writings towards Turkish Course and/ happy emoji/ hearts/flowers & 137 & 32,6 \\
Class/teacher/student/wood & 129 & 30,7 \\
Book/ course book/student who read a book/speech bubble that is written «I love & 79 & 18,8 \\
reading» & 44 \\
Negative emoji/bored gestures/writings that express negative emotions towards Turkish & 10,4 \\
course or teacher & 43 \\
Flag/Ataturk/Turkish World mottos/the super hero «Turkish man» & 13,09 \\
Light/torch/bearer tree & 10 \\
The ones who cannot draw & 7,3 \\
Total & 419 & 1,9 \\
\hline
\end{tabular}

When the drawings of students on Turkish course are examined, it is seen that most of the drawings are positive towards the Turkish course. Apart from that, the students who perceive the course within the triangle of classroomteacher-student also represent an important number. In addition, it is understood that the course is associated with a book.

\section{Discussion and Conclusion}

In this research, it was aimed to determine the attitudes towards Turkish course, the relationship between the attitudes and variables, and the metaphors toward Turkish teacher and course. In the direction of this aim, the results obtained from the research study are provided in this section.

It was understood that the students' attitudes towards the Turkish course, was at a medium level (\% 57). Yaman (2014), Erdem and Gozukucuk (2013), Zorbaz and Habes (2015) also reached to a similar result in their studies. In addition to that, Bolukbas (2010) observed a positive attitude at a \% 67 rate towards Turkish course. It is seen that as the grade levels of students increase, their attitude scores decrease. The same results were reached in the study conducted by Deniz and Tuna (2006). In parallel with these results, it was determined by Zorbaz and Habes (2015) that the 5th-grade students have a more positive attitude towards the one at 6th,7th, and 8th-grade students.

Furthermore, it was found out that female students' attitudes towards the Turkish course are more positive in comparison to male students' attitudes. Kaya et al. (2009), Bolukbas (2010), Gur et al. (2013), Kazazoglu (2013), Zorbaz and Habes (2015) demonstrated that females students have a more positive attitude towards Turkish course in comparison to male students. 
It was seen that students who consider themselves as more competent in reading activity have more positive attitudes towards Turkish course also have a higher level of comprehension. According to the study carried out by Zorbaz and Habes (2015), the attitudes of students who have a habit of reading is more positive in comparison to the ones who read less. These findings reveal the necessity of developing positive attitudes towards Turkish course.

It was understood that the attitudes of students- whose number of profiles are increasing- are affected negatively. A similar situation is also relevant for the students who possess a cell phone. The attitudes of students towards Turkish course also occurred negatively in comparison to the one who does not possess a phone. In the study that Demirer, Yildiz and Sunbul (2011) conducted in the province of Konya by reaching almost all of the universe that, the use of computer and internet affects students reading habits negatively. In addition, in the study that Armut (2017) conducted to examine the relationship between the use of social media and mellifluous reading skills, it was found out that the ones who have a social media account are able to read more mellifluously in general sense in three different text types in comparison to the ones who do not have a social media account.

The attitudes of students, who like their teacher and participate in extracurricular activities, towards the Turkish course also occurred in a more positive way. In this way, it can be suggested for Turkish teachers to conduct extracurricular activities with their students. It was seen that the attitudes of students decrease towards the Turkish course with increasing levels of maternal and paternal education levels. However, the statistical significance occurred only between the children of mothers and fathers who are primary school graduates, and children of mothers and fathers who are university graduates. On the other hand, it was seen that as the maternal and paternal education levels increase the attitudes of students towards the Turkish course also increases. Kaya et al. (2009) and Zorbaz and Habes (2015) could not reach any relations between maternal and paternal education levels and attitudes of students towards the Turkish course.

According to the qualitative findings of the study, it was understood that students who participated in the study have a positive perception towards their teachers in a general sense. Indeed, the fact that more than half of the students drew an analogy on their teachers by expressing creatures as angel/panda/book/sun/candle/star etc. constitutes a base for this situation.

Besides, approximately \%10 of the students drew negative analogies on their teachers as "Hitler, dictator, gunpowder, dragon". In addition, according to the analogies, it is understood that participant students draw analogies on their teachers by expressing that they look like concrete things as "cotton, book, sun, candle". De Guerrrero and Villamil (2002), made participants to complete a sentence as "An English teacher is like....". As a result of the study, the metaphors developed on teachers were separated into nine concept fields. According to this, different metaphors on teachers were developed in the frameworks of a collaborative leader, informative, resistant to change or support it, nurturer, progressive, artist, repairer, physical education coach. For example, on a teacher, the analogy of movie/theater/ symphony director on the "collaborative leader" category; analogy of moon, sun, a tree full of apples on the "informative" category; analogy of bee, Mother Nature, a gardener on the "nurturer" category.

When the issue is considered from the perspective of students' gender, it is seen that both female and male students appeal to analogies that mainly reflect teachers' characteristics of being knowledgeable, guiding, and being good. According to this, this situation can be interpreted as teachers are seen as the ones who have the absolute knowledge, and in addition to this they are considered as guides, and their personal characteristics are given importance. When the analogies are addressed in terms of the grade levels of students, it is understood that 5th and 8th-grade students put more attention on teachers' characteristic of being known, on the other hand, 6th and 7th-grade level students focus more on the characteristic of being good.

In the research study, the participants were asked to give information on what they think their teacher look like with their current status and also what they would like them to be. According to this, more than half of the students left this question empty or expresses that they do not want their students to be like anything else. Starting from this point of view, it is understood that more than half of the students are not in favour of a change in their Turkish teachers. In addition to that, \%26,1 of the students would like their teachers to be "better, more amusing, calmer, more cheerful etc.". This situation can be interpreted as $4 / 1$ of the students are not satisfied with the current situation and wish them to have better qualities.

Besides asking students to make analogies by writing, they were also asked to make drawings that express their emotions concerning the Turkish Course. At this point, \%32,6 of the students made positive drawings, drew emojis that express happiness; and expressed their feelings with hearts and flowers. A \%30,7 of the students drew a classic classroom that consisted of components of "classroom, student, teacher and blackboard".

When the literature on qualitative results is compared, it is seen that there is a consistency with the findings of this study. Likewise, in their study on the metaphors of 5th and 6th-grade students towards the concepts of teacher and school, Kuyumcu and Ozsari (2016) determined that most of the students mainly developed concrete, non-alive and positive metaphors; and on the concept of the teacher, they presented concrete, alive and positive metaphors. Gedikli (2014) presented that secondary school students have a positive perception of Turkish teachers through metaphors. 
On the other hand, the fact that an important number of students consider their Turkish teacher as a sourcetransmitter of information was interpreted by the writer that the impacts of the behaviorist approach are still evident in education. Karabay (2016) who tried to identify the professional identities of Turkish teachers determined that the prospective teachers see the profession of teaching as a source of information as a source of information. In the studies of Oxford et al. (1998), metaphors such as "a teacher as a channel, teacher as a nurturer and teacher as a contester" were presented. Nikitina and Furuoka (2008), who examined the metaphors that Malaysian students developed on their language teacher demonstrated that the typologies of Oxford et al. (1998) are applicable in the context of Malaysian education. Kucuktepe, Eminoglu and Gurultu (2014) tried to reveal the metaphors of teachers on constructivist learning approach. They found out that constructivist teachers are perceived as a "guide, a source of information, former, information sharer-enlightener, solution maker- discoverer, administrative, preserver, as an expert, as a source of life and hard-working teacher.

Some weaknesses and limitations can be reported for this study: Firstly, for more comparable results, a larger sample must be reached in the following studies. If it is possible, samples from various cities and regions in Turkey must be determined. In this way, it would be possible to understand whether there is a harmony in Turkish education system in terms of the new education approach. Similar studies can be supported interviews with the students and teachers. Focus group discussion can be conducted for this aim.

\section{Acknowledgements}

This research study was supported in the scope of Project number EGT. A4. 18.017 of Ahi Evran University BAP Unit.

\section{References}

Akin, E., \& Cecen, M. A. (2015). Coklu ortam uygulamalarina dayali ogretimin 6. sinif ogrencilerinin anlama becerilerine ve Turkce dersi tutumlarina etkisi (Mus ili ornegi) [The effect of multimedia based teaching on 6th grade students' comprehension skills and attitudes towards Turkish lesson (sample of Mus province)]. The Journal of International Education Science, 2(5), 285-309.

Akkaya, N. (2011). Ilkogretim 6. sinif Turkce dersinde yaratici yazma yaklasiminin Turkce dersine yonelik tutuma etkisi [The effect of creative writing approach on Turkish course in Turkish classes at 6th grade]. Dokuz Eylul University Journal of Buca Faculty of Education, 30, 311-319.

Aksan. D. (2003). Her yonuyle dil ana cizgileriyle dilbilim [Language in all aspects, linguistics]. Ankara: TDK.

Allport, G. W. (1967). Attitudes. Martin Fishbein (Ed.). Readings in attitude theory and measurement. New York: John Wiley.

Armut, M. (2017). Ortaokul ogrencilerinin akici okuma becerilerinin cesitli degiskenler acisindan incelenmesi (Yozgat ili ornegi) [The examination of middle school students' fluent reading skills in terms of various variables (Yozgat province sample)]. (Unpublished Master's Thesis). Kirsehir Ahi Evran University, Kirsehir.

Arslan, A., Sahin, A., Sahin, E., \& Akcay, A. (2011). Yaratici drama yonteminin ilkogretim 6. sinif ogrencilerinin Turkce dersi tutumlarina etkisi [Effect of creative drama method on $6^{\text {th }}$ grade students' attitude towards Turkish course]. The Journal of National Education, 190, 234-246.

Aslan, A. (2009). Bilgisayar destekli Turkce ogretiminin ogrencilerin Turkce dersi tutumlarina etkisi [Affection of the Turkish instruction in support of computer method to the attitudes of the students of Turkish lesson]. Education Sciences, 4(2), 665-677.

Ates, M. (2008). Ilkogretim ikinci kademe ogrencilerinin okudugunu anlama duzeyleri ile Turkce dersine karsi tutumlari ve akademik basarilari arasindaki iliski [The relations between reading abilities of students at the second stage of primary school and their attitudes to Turkish lesson and their academic achievement were studied] (Unpublished Doctoral Dissertation). Selcuk University, Konya, Turkey.

Belet, S., \& Yasar, S. (2007). Ogrenme stratejilerinin okudugunu anlama ve yazma becerileri ile Turkce dersine iliskin tutumlara etkisi [Effectiveness of learning strategies over reading comprehension, writing skills and learners' attitudes towards Turkish course]. Journal of Theory and Practice in Education, 3(1), 69-86.

Berliner, D. C. (1990). If the metaphor fits, why not wear it? The teacher as executive. Theory into practice, 29(2), 85-93.

Bohner, G., \& Wanke, M. (2002). Attitudes and attitude change. Philadelphia: Psychology Press.

Bolukbas, F. (2010). Ilkogretim ogrencilerinin Turkce dersine yonelik tutumlarinin basari-cinsiyet-ailenin egitim duzeyi baglaminda degerlendirilmesi [Evaluation of the attitudes of the elementary school students to Turkish course in terms of success-gender education level of their families]. Turkish Studies. 5(3). 905-918.

Brown, C. (2006). Social psychology. California: Sage Publications Ltd. 
Brown, T. A. (2006). Confirmatory factor analysis for applied research. New York: Guilford Press.

Browne, M.W., \& Cudeck, R. (1993). Alternative ways of assessing model fit. In K. A. Bollen \& J. S. Long (Eds.), Testing structural equation models (pp. 136-162), CA: Sage, Newbury Park.

Byrne, B. M. (2010). Structural equation modeling with AMOS. (2 nd. Edt.), Routledge, New York.

Crano, W. D., \& Prislin, R. (2006). Attitudes and persuasion. Annual Review of Psychology. 57, 345- 374.

Corek, D. (2006). Isbirlikli ogrenmenin Turkce dersine iliskin basari ve derse yonelik tutum uzerindeki etkileri [The effects of cooperative learning on the achievement in the Turkish course and attitudes] (Unpublished Doctoral Dissertation). Dokuz Eylul University, Izmir, Turkey.

De Guerrero, M. C., \& Villamil, O. S. (2002). Metaphorical conceptualizations of ESL teaching and learning. Language Teaching Research, 6(2), 95-120.

Demirci, K. (2016). Metafor: bir anlatim ve uretim mekanizmasi [Metaphor: a narrative and producing mechanism]. Dil bilimleri kultur ve edebiyat (Edt. M. Sarica, B. Sarica). Ankara: Padam Yayinlari, 330-343.

Demirer, V., Cintas Yildiz, D., \& Sunbul, A. M. (2011). Ilkogretim ogrencilerinin bilgisayar ve internet kullanimlari ile kitap okuma aliskanliklari arasindaki iliski: Konya ili ornegi [The Relationship between primary school students' computer internet usage and reading habits: Sample of Konya]. Elementary Education Online, 10(3), 1028-1036.

Deniz, S., \& Tuna, S. (2006). Ilkogretim ogrencilerinin Turkce dersine yonelik tutumlari: Koycegiz orneklemi [The attitudes of primary students towards Turkish course: The sample of Koycegiz]. The Journal of National Education, 34(170), 339-350

Erdem, A. R., \& Gozukucuk, M. (2013). Ilkogretim 3. 4. ve 5. sinif ogrencilerinin Turkce dersine yonelik motivasyonu ve tutumlari arasindaki iliski [The relationship between motivation and attitudes of the $3^{\text {rd }}, 4^{\text {th }}, 5^{\text {th }}$, class primary students for Turkish lessons]. Pegem Journal of Education \& Training, 3(2), 13-24.

Fidan, M., \& Eren, A. (2017). Ortaokul Ogrencilerinin Turkce Dersine Yonelik Tutum Gorunumleri Ile Egitime Iliskin Motivasyonlari Arasindaki Iliskiler [Relationships Between the Profiles of Middle School Students' Attitudes Towards Turkish Course and Motivations for Education]. Hacettepe University Journal of Education), 32(2), 480493.

Field, A. (2005). Discovering Statistics Using SPSS. (2 nd ed.). London: Sage Publications.

Fishbein, M., \& Ajzen, I. (1975). Belief, attitude, intention, and behaviour: an introduction to theory and research. Reading. MA: Addison-Wesley.

Gedikli, 0. (2014). Ortaokul 2, 3 ve 4. sinif ogrencilerinin Turkce ogretmenini algilayisinin metaforlar araciligiyla belirlenmesi [Determination of 6th, 7th and 8th grade students' Turkish teacher perceptions via "metaphors"]. (Unpublished Master's Thesis). Karadeniz Teknik University, Trabzon.

Gur, T., Dilci, T., Sener, H., \& Yildirim, T. (2013). 4. sinif ogrencilerinin Turkce dersine yonelik tutumlarina bazi degiskenlerin etkileri. Cumhuriyet International Journal of Education, 2(1). 118-134.

Incelioglu, M. (2004). Tutum algi iletisim [Attitudes, perception, communication]. Ankara: Elips Kitap.

Joreskog, Karl G. \& Sorbom D. (1993). Lisrel 8: Structural equation modeling with the SIMPLIS Command Language. Lincolnwood, Scientific Software International.

Kapar-Kuvanc, E. B. (2008). Yaratici yazma tekniklerinin ogrencilerin Turkce dersine iliskin tutumlarina ve Turkce dersindeki basarilarina etkisi [The effect of creative writing techniques to students' attitudes to Turkish course and their sucesses in Turkish courses]. (master thesis), Dokuz Eylul University, Izmir.

Karabay, A. (2016). An investigation of prospective teachers' views regarding teacher identity via metaphors. Eurasian Journal of Educational Research, 65, 1-18.

Karasar, N. (2008). Bilimsel arastirma yontemi [Scientific research method]. Ankara: Nobel.

Kaya, A. I., Arslantas, H. I. \& Simsek, N. (2009) Ilkogretim ogrencilerinin turkce tutumlarinin degerlendirilmesi [The elementary school students' towards Turkish courses determinates of their attitudes]. Electronic Journal of Social Studies, 30, 367-387.

Kayiran, B. K., \& Iflazoglu, A. (2007). Coklu zeka kurami destekli kubasik ogrenme yonteminin Turkce dersine iliskin tutuma ve okudugunu anlama basarisina etkisi [The effect of cooperative learning method supported by multiple intelligences theory on the attitude and reading comprehension success of the Turkish course]. Eurasian Journal of Educational Research (EJER), 29(3), 129-141. 
Kazazoglu, S. (2013). Turkce ve Ingilizce derslerine yonelik tutumun akademik basariya etkisi [The effect of attitudes towards Turkish and English courses on academic achievement]. Education and Science. 38 (170). $294-307$.

Kline, R. B. (2005), Principles and practice of structural equation modeling (2 nd Edt.), Guilford Press, New York.

Kuyumcu, F. N., \& Ozsari, I. (2016). 5. ve 6. sinif ogrencilerinin ogretmen ve okul kavramlarina iliskin algilarinin degerlendirilmesi [An evaluation of the 5. and 6. grade students' perceptions on the concepts of teacher and school]. Journal of Research in Education and Teaching, 5(44), 396-407.

Kucuktepe, S. E., \& Gurultu, E. (2014). Ogretmenlerin “yapilandirmaci ogretmen” kavramina iliskin algilarina yonelik metafor calismasi ornegi [Sample of metaphor study aimed at perception of teacher's related to notion of "constructivist teacher"]. Abant Izzet Baysal University Journal of Faculty of Education, 14(2), 282-305.

Lakoff, G., \& Johnson, M. (2005). Metaforlar hayat, anlam ve dil[Metaphors, life, meaning and language]. Istanbul: Paradigma.

Manguel, A. (2018). Gezgin, kule ve kitapkurdu [The traveler, the tower, and the worm - the reader as metaphor]. Istanbul: YKY Yayinlari.

Mc Kenna, M. C., Kear, D. C., \& Ellsworth, R. A. (1995). Children's attitudes toward reading: A national survey. Reading Research Quarterly, 30(4), 934-956.

Nikitina, L., \& Furuoka, F. (2008). " a language teacher is like...": examining Malaysian students' perceptions of language teachers through metaphor analysis. Online Submission, 5(2), 192-205.

Oskamp, S. \& Schultz, P. W. (2005). Attitudes and opinions. (3. ed.). London: Lawrence Erlbaum Associates.

Oxford, R. L., Tomlinson, S., Barcelos, A., Harrington, C., Lavine, R. Z., Saleh, A. \& Longhini, A. (1998). Clashing metaphors about classroom teachers: Toward a systematic typology for the language teaching field. System, 26(1), 3-50.

Raykov, T. \& Marcoulides, George A. (2006). A first course in structural equation modeling, Lawrence Erlbaum Associates, Inc., Publishers, New Jersey.

Sahinli, A. (2008). Hikâye okumanin okudugunu anlamaya ve Turkce dersine yonelik tutuma etkisi [The effect of reading stories on comprehending what has been read and atitude of students towards Turkish lesson], (master thesis), Dokuz Eylul University, Izmir.

Tasdemir, M. (2003). Egitimde planlama ve degerlendirme [Planning and evaluation in education]. (2 ${ }^{\text {rd }}$ ). Ankara: Ocak Publishing.

Taser, S. (2012). Konusma egitimi [Speaking education]. Istanbul: Pegasus Publishing.

Tavsancil, E. (2006). Tutumlarin olculmesi ve SPSS ile veri analizi [The measurement of attitudes and data analyse with SPSS]. Ankara: Nobel Publishing.

Topcuoglu Unal, F., \& Kose, M. (2014). Turkce dersine yonelik tutum olcegi gelistirilmesi: Bir gecerlilik ve guvenirlik calismasi [Developing a Turkish lesson attitude scale: A validity and reliability study]. Bartin University Journal of Faculty of Education, 3(2), 233-249.

Tuzemen, T., \& Kardas, M. N. (2017). Akademik celiski tekniginin ogrencilerin Turkce dersine yonelik tutumlarina etkisi ve bazi degiskenlerle iliskisi [The effect of the academic contradiction technique on the speech anxiety of 6th grade students and some variables]. The Journal of Social Sicences Institute, 1(38), 127-150.

Yaman, H. (2014). Ortaokul ogrencilerinin genel kaygi duzeyleri, yazma kaygilari ve Turkce dersine yonelik tutumlari arasindaki iliski [The relation general anxiety levels, anxiety of writing, and attitude for Turkish course of secondary school students]. Educational Sciences: Theory \& Practice, 14(3), 1111-1122.

Yildirim, M. \& Erdogan, T. (2016). Yaratici drama yonteminin ilkokul ikinci sinif ogrencilerinin Turkce dersine iliskin tutumlarina etkisi [The Effect of creative drama on second grade students in elementary school related to Turkish course]. Creative Drama Journal, 11(1), 71-88.

Yildirim, A. \& Simsek, H. (2013) Sosyal bilimlerde nitel arastirma yontemleri [The quantitative research methods in social sciences]. Ankara: Seckin Publishing.

Zorbaz, K. Z., \& Habes, M. (2015). Ortaokul ogrencilerinin Turkce dersine yonelik tutumlarinin cesitli degiskenler acisindan incelenmesi [Measuring the attitudes of secondary school students towards Turkish language with regard to various variables]. Kastamonu Education Journal, 23(4), 1733-1752. 